[Agr. Biol. Chem., Vol. 30, No. 4, p. 423 424, 1966]

\title{
3-Phenoxypyridazine as a New Selective Herbicide
}

Sir:

During the course of our screening tests to get new potent herbicides, we found out through the petri dish method that some phenoxypyridazines such as 3-chloro-6-phenoxypyridazine (I) and 3-chloro-6-(2, 6-dichlorophenoxy)pyridazine (II) showed the strongest pre-emergent herbicidal activity among more than a hundred pyridazine derivatives tested. ${ }^{1,2}$ Recently we noticed, however, that in the submerged pot test, the condition of which bears close resemblance to that of the paddy field, the herbicidal activity of 3-phenoxypyridazine (III) containing no substituent on its pyridazine and benzene rings was far superior to those of other phenoxypyridazines. In this paper we wish to report the efficiency of this compound as a selective herbicide.

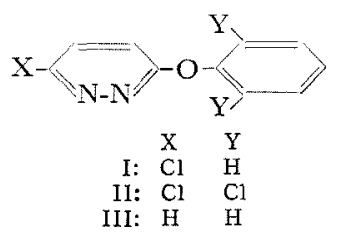

$\mathrm{III}^{3)}$ and related 3-phenoxypyridazines tested except 3-(3-nitrophenoxy)pyridazine (IV) were prepared in high yields by catalytic hydrogenation of corresponding 3-chloro-6phenoxypyridazines over $5 \%$ palladium-oncharcoal or Raney nickel in ammoniamethanol at ordinary pressure and room temperature. In these cases the chlorine atom on the benzene ring was never attacked by hydrogen. On the other hand, all attempts to prepare 3-phenoxypyridazines by treatment of corresponding 3-chloro-6-phenoxypyridazines with zinc dust or iron powder in

1) S. Tamura and T. Jojima, This Journal, 27, 728 (1963).

2) T. Jojima and S. Tamura, ibid., 29, 157 (1965).

3) T. Itai and H. Igeta, J. Pharm. Soc. Japan, 74, 1195 (1954). appropriate solvents were unsuccessful resulting in cleavage of the ether linkage. IV was synthesized by fusion of 3-chloropyridazine with $m$-nitrophenol in the presence of anhydrous potassium carbonate.

The method mainly employed here for the evaluation of the compounds as herbicides to be used on paddy fields was the submerged pot test. In this test small plastics pots were filled with paddy field soil, in which seeds of barn-yard grass (Echinochloa Crus-galli L.) were sown and seedlings of spikerush* (Eleocharis acicularis $\mathrm{R}$. Br.) and rice (Oryza sativa var. Koshihikari) transplanted together, and then watered. After germination of the barnyard grass, solutions of the test compounds were poured into the pots at serial dilutions, and results were observed after three weeks.

As summarized in the Table which shows only typical data, I and III exhibited almost equal activity in the germination test. However, in the submerged pot test the effects of III was far more excellent than that of I to barnyard grass and spikerush, which are the most noxious weeds on paddy fields in our country. III completely killed these weeds at the dosage corresponding to $250 \mathrm{~g}$. per 10 ares, whereas it was nearly harmless to rice plants at this concentration. It is worthy to note that substitution on the benzene ring of III never enhanced the activity and that IV was almost completely inactive.

Responses, which have been hitherto revealed preliminarily, of various cultivated plants to III are as follows: Susceptible-barley and carrot. Unsusceptible-radish, rapeseed, cotton, corn and tomatoe.

The mammalian toxicity of III is very low, the interperitoneal $\mathrm{LD}_{50}$ to mice being more than $200 \mathrm{mg} . / \mathrm{Kg}$. The fish toxicity is also

\footnotetext{
* Japanese common name: Matsubai.
} 
TABLE I. HeRbicidal ACtivities of 3-PhenOXYPYRIDAZINES

\begin{tabular}{ll}
$\mathrm{X}$ & \multicolumn{1}{c}{$\mathrm{R}$} \\
$\mathrm{X}$ & \multicolumn{1}{c}{$\mathrm{R}$} \\
$\mathrm{H}$ & $\mathrm{C}_{6} \mathrm{H}_{5}$ \\
$\mathrm{H}$ & $3-\mathrm{CH}_{3}-\mathrm{C}_{6} \mathrm{H}_{4}$ \\
$\mathrm{H}$ & $3-\mathrm{Cl}_{-} \mathrm{C}_{6} \mathrm{H}_{4}$ \\
$\mathrm{H}$ & $2-\mathrm{C}_{6} \mathrm{H}_{5}-\mathrm{C}_{6} \mathrm{H}_{4}$ \\
$\mathrm{H}$ & $3-\mathrm{CH}_{3}-4-\mathrm{Cl}_{-}-\mathrm{C}_{6} \mathrm{H}_{3}$ \\
$\mathrm{H}$ & $2,4-\mathrm{di}_{-}-\mathrm{Cl}-\mathrm{C}_{6} \mathrm{H}_{3}$ \\
$\mathrm{H}$ & $4-\mathrm{CH}_{3} \mathrm{O}-\mathrm{C}_{6} \mathrm{H}_{4}$ \\
$\mathrm{H}$ & $3-\mathrm{NO}_{2}-\mathrm{C}_{6} \mathrm{H}_{4}$ \\
Cl & $\mathrm{C}_{6} \mathrm{H}_{5}$
\end{tabular}

\begin{tabular}{|c|c|c|}
\hline \multirow{2}{*}{ M.p., ${ }^{\circ} \mathrm{C}$} & \multicolumn{2}{|c|}{$\begin{array}{c}\text { Germination } \\
\text { test, } 30 \text { p. p. m. }\end{array}$} \\
\hline & B & Tel \\
\hline $71 d)$ & H & + \\
\hline 47 & $x$ & - \\
\hline 90.5 & $x$ & $H$ \\
\hline $122 \sim 123$ & $x$ & $H$ \\
\hline 86 & + & $H$ \\
\hline 98 & + & - \\
\hline 88.5 & - & - \\
\hline 86 & + & - \\
\hline $69 \sim 70$ & H & + \\
\hline
\end{tabular}

$\begin{array}{ccr}\begin{array}{c}\text { Submerged pot test, } \\ 250 \mathrm{~g} \cdot / 10 \mathrm{a} . \mathrm{b})\end{array} \\ \mathrm{B} & \mathrm{S} & \mathrm{R}(\mathrm{c}) \\ 5 & 5 & 0 \\ 5 & 4 \sim 5 & 0 \\ 5 & 3 \sim 4 & 0 \\ 5 & 0 \sim 1 & 0 \\ 5 & 1 \sim 2 & 0 \\ 5 & 3 & 0 \\ 1 & 0 & 0 \\ 0 & 0 & 0 \\ 1 & 1 \sim 2 & 0\end{array}$

a) Experimental procedure and herbicidal rating are the same to those in the previous paper. ${ }^{1}$

b) Herbicidal ratings are as follows:

$0:$ no inhibition, 1: $25 \%$ or lower inhibition, 2: $25 \sim 50 \%$ inhibition, 3: $50 \sim 75 \%$ inhibition,

4: $75 \%$ or higher inhibition, 5: no germination or complete killing.

c) B: barnyard grass, T: Taisai (Brassica chinensis), S: spikerush, R: rice.

d) Lit., 3) $74 \sim 75^{\circ} \mathrm{C}$.

low, and no effects were observed to infant carps even at 10 p. p. m. after 48 hrs. $^{*}$

Thus, III has been proved to be a promising herbicide, and large scale examinations on its utility are now being in progress.

The marked growth regulating activity of III quite similar to that of maleic hydrazide, though more specific than the latter to plant species, will be reported later.

Acknowledgement. We wish to thank $\mathrm{Mr}$. $\mathrm{K}$. Oyamada for cooperation in the hydrogenation experiment. We are also indebted for

* All the infant carps were killed by sodium pentachlorophenolate at 1 p. p. m. in this experiment.
Mr. T. Honma for assistance during $t$ herbicidal test.

\section{Saburo Tamura \\ Teruomi Jojima* \\ Katsuhiko KaWaKUBo* \\ Keiichi Nakamura* \\ Tetsuo Takematsu**}

Department of Agricultural Chemistry

The University of Tokyo, Tokyo

*Agricultural Chemicals Laboratory

Sankyo Co. Ltd., Tokyo

**Faculty of Agricultnre

Utsunomiya University, Utsunomiya

Received March 2, 1s 